\title{
Superheroes, supervillains, and universal health care
}

\author{
Gilbert Berdine MD
}

The superhero is a very popular plot element today. The Avengers, the X-Men, the Justice League, and Game of Thrones all feature characters with fantastic powers. These characters are considered superheroes if they help people. These characters are considered supervillains if they hurt people. Sometimes it is not clear which category fits a given character. Sometimes an apparent superhero becomes a supervillain prompting a fan revolt demanding a plot change (Game of Thrones).

Why are superheroes needed by ordinary people? The stories feature some element that is going to do great harm to a number of ordinary people, and these people require the superhero to intervene on their behalf. Sometimes, the harm will result due to a natural calamity. More often, the harm is due to the strong preying upon the weak. Sometimes the strong are represented by a supervillain who preys on ordinary people rather than just the weak. This last scenario is important because it is never explained that the super power is the root of the problem rather than its cure.

The real world contains bad people who prey upon the weak. This is a great motivation for individuals to group together to form a common defense. The need for common defense against bad people is probably the strongest argument against a society based solely upon individual liberty. Individuals would be no match for bands of criminals intent on doing them harm. The problem is not the weakness of individuals; rather the problem is the concentration of power in bands of criminals. Society must organize to protect itself against concentrated power. The superhero can be a metaphor for a government protecting its citizens against aggression from external

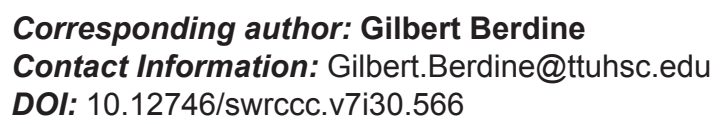

enemies. The question remains how powerful must society become to protect itself? When does further concentration of power in a central authority lead to tyranny over the very people who are supposed to be protected by that authority? When does further concentration of power lead to tyranny over neighboring societies rather than serving as self-defense? When do superheroes become supervillains?

Illness is a type of villain. Some illnesses have similar features as supervillains; ordinary people are powerless to defend themselves against the superillness. Ordinary people need a superhero to protect them from the superillness. Just as central government assumes the mantle of superhero to protect citizens from bad people, the central government is considered the only entity with sufficient resources to protect citizens from illness. Hence, an increasing call for universal health care provided by government agencies. The New England Journal of Medicine recently featured a commentary about popular demand for government solutions to health care problems. ${ }^{1}$ The commentary discussed polls that demonstrate that the public is concerned about the high cost of health care. In particular, the public is concerned about the high cost of hospitalization and pharmaceuticals. The hospitals and the pharmaceutical companies become the supervillain. Government assumes the role of superhero. As with the superhero movie or comic, it is left unstated how the concentration of power into the hands of hospitals and pharmaceutical companies by government privileges (patent monopolies and licensure) created the high cost of health care in the first place. The concentration of power in "bad" hands creates the need for a superhero, but the superhero would be unnecessary without the supervillain that would not exist without the superpower. Concentration of power is the evil rather than the person controlling it.

The basic plot structure of superhero stories give insight as to the limits of what superheroes can do. Superman saves the day when a tornado threatens a small town, but Superman does not cultivate all 
the wheat fields so that farmers can take a vacation. The superhero is called upon for isolated, existential threats rather than to solve our everyday problems of supplying basic needs.

Does the government have the resources to provide health care that is not affordable by entire communities for their citizens? There is no reason to believe so. Government does not produce anything; rather government wastes resources by diverting them from satisfying economic demand dictated by prices so that politically motivated ends can be satisfied first. If something is not affordable by the average citizen, there is no reason to believe that government can afford to provide this something to everyone. Some ends can be satisfied by taking from the rich, but the ends demanded by average people are no more affordable to the group than to the average individual.

So, if further concentration of power over health care supply and demand cannot provide what average people cannot afford, how much centralization of health care is enough? How much is too much? When does centralized health care cease to be a superhero and become a supervillain? The New England Journal of Medicine commentary does not address these questions.

When government assumes the role of superhero, ordinary people lose control of whatever government decides to do. As mentioned above, government cannot afford pharmaceuticals any more than ordinary people can afford them. When government steps in to "provide", the government decides who will get pharmaceuticals and who will not. If the pharmaceuticals were affordable to the average person, individuals could decide if they had sufficient need to purchase the drug rather than some bureaucrat. By granting pharmaceutical companies monopoly privileges, government makes pharmaceuticals unaffordable. Government steps in to "provide" pharmaceuticals to the needy, but then government decides who is needy and who is not. Restriction to access by bureaucratic fiat is just as much a denial of care as restriction by unaffordable price. There is no more a right to health care when government provides it or subsidizes it than when allocation is determined by the market.

Do Americans want health care decisions made by local people? Or by bureaucrats in national agencies? Do we want a health care system without supervillains and without superheroes? Or do we really want Thor duking it out with Thanos? These would make for interesting poll questions, but these are not the questions that are asked. There should be no surprise that people want free stuff. There should also be no surprise that these same people assume somebody else will pay for the free stuff. Americans favor universal health care until they discover what the price tag will be for stuff advertised as "free."

Keywords: Health care, costs, government control

Article citation: Berdine G. Superheroes, supervillains, and universal health care. The Southwest Respiratory and Critical Care Chronicles 2019;7(30):69-70

From: Department of Internal Medicine, Texas Tech University Health Sciences Center, Lubbock, Texas

Submitted: $7 / 1 / 2019$

Conflicts of interest: none

This work is licensed under a Creative Commons Attribution-ShareAlike 4.0 International License.

\section{REFERENCE}

1. Blendon RJ, Benson JM, McMurty CL. The upcoming U.S. health care cost debate- the public's views. N Engl J Med 2019;380:2487-2492. 